\title{
Reaching beyond Banks: How to Target Trade- Based Money Laundering and Terrorist Financing Outside the Financial Sector
}

\author{
Ross S. Delston \\ Stephen C. Walls
}

Follow this and additional works at: https://scholarlycommons.law.case.edu/jil

Part of the International Law Commons

\section{Recommended Citation}

Ross S. Delston and Stephen C. Walls, Reaching beyond Banks: How to Target Trade-Based Money Laundering and Terrorist Financing Outside the Financial Sector, 41 Case W. Res. J. Int'l L. 85 (2009)

Available at: https://scholarlycommons.law.case.edu/jil/vol41/iss $1 / 5$ 


\title{
REACHING BEYOND BANKS: HoW TO TARGET TRADE-BASED MONEY LAUNDERING AND TERRORIST FINANCING OUTSIDE THE FINANCIAL SECTOR*
}

\author{
Ross S. Delston ${ }^{\dagger}$ \& Stephen C. Walls
}

Anti-money laundering and combating the financing of terrorism (AML/CFT) measures have succeeded in restricting the two traditional avenues of money laundering, namely, the abuse of financial intermediaries and the physical movement of money across borders. Consequently, international criminal and terrorist organizations have turned to trade-based money laundering (TBML) to conceal and legitimize their funds, as this is a channel that remains relatively untouched by AML/CFT efforts internationally. This abuse of the global trade network has received increasing recognition from the Financial Action Task Force, the international standardsetter, as the next front in $A M L / C F T$. Because TBML methods may be used not only to launder money, but also to finance international terrorism, to facilitate weapons proliferation, and to conceal and transport WMDs, this article proposes a far-reaching solution-that those in the international supply chain be required by law to adopt AML/CFT safeguards to protect their businesses, including filing suspicious activity reports, identifying their customers, and designating an AML/CFT compliance officer.

\section{INTRODUCTION}

The international fight against money laundering began in the 1960s, but with the signing of the United Nations Convention Against Illicit

\footnotetext{
* Portions of this article are based in part on Ross Delston's earlier article entitled The $41^{\text {st }}$ FATF Recommendation: Why preventive measures targeting trade-based money laundering should reach beyond banks, MONEY LAUNDERING BULlETIN (March 2008), at 8, reprinted as The $41^{\text {st }}$ FATF Recommendation: Why banks alone cannot prevent trade-based money laundering, ACAMS TODAY, (July/Aug. 2008), at 42.

$\dagger$ Ross S. Delston (J.D. with honors, The George Washington University Law School, 1976), CAMS (Certified Anti-Money Laundering Specialist) is a Washington, DC lawyer and the founder of GlobalAML.com, a consulting firm specializing in anti-money laundering compliance. Former positions include Consulting Counsel, AML/CFT Unit, International Monetary Fund (2000-05), Counsel and Assistant General Counsel-Assisted Acquisitions, Federal Deposit Insurance Corporation (1986-91), and Counsel, Export-Import Bank of the U.S (1976-86).

$\$ \quad$ Stephen C. Walls (J.D. with honors, The George Washington University Law School, 2008) will be a R. Michael Gadbaw Fellow on the International Law \& Policy Team of the General Electric Company in Washington D.C. during 2009.
} 
Traffic in Narcotic Drugs and Psychotropic Substances in December 1988, ${ }^{1}$ efforts to target money laundering became a major international focus. Since its inception in $1990{ }^{2}$ the Financial Action Task Force (FATF), an intergovernmental organization formed to help countries combat money laundering and terrorist financing, has focused considerable attention on the role of financial institutions, and, more recently, ${ }^{3}$ the physical movement of money across borders. ${ }^{4}$ The fight against money laundering and international terrorism in recent years has highlighted a third method by which illicit funds may be transferred across borders: abuse of the international trade system. ${ }^{5}$ The FATF has signaled its interest in Trade-Based Money Laundering (TBML) by its publication of a report entitled "Trade Based Money Laundering" (TBML Report) in June 2006. ${ }^{6}$ Subsequently, in June 2008, the FATF issued its "Best Practices Paper on Trade Based Money Laundering" (FATF Best Practices Paper), providing more detail about TBML and how to prevent it. ${ }^{7}$

The TBML Report and the Best Practices Paper (collectively, the FATF Reports) identify TBML as one of the three main avenues of money laundering, ${ }^{8}$ and define TBML as the process of legitimizing the proceeds of crime by moving value through trade transactions to disguise their illicit origins. ${ }^{9}$ The FATF Reports describe several examples of TBML that have occurred in the laundering of drug profits and terrorist financing. ${ }^{10}$

1 U.N. Convention Against Illicit Traffic in Narcotic Drugs and Psychotropic Substances, Dec. 20, 1988, 1582 U.N.T.S. 165, 170, available at http://www.unodc.org/pdf/conventio n_1988_en.pdf [hereinafter The 1988 Vienna Convention]. According to the U.N. Office on Drugs and Crime, the Vienna Convention is "the first international convention which criminalises [sic] money-laundering." U.N. Office on Drugs and Crime, U.N. Instruments and Other Relevant International Standards on Money-Laundering and Terrorist Financing, http://www.unodc.org/unodc/en/money-laundering/Instruments-Standards.html (last visited Feb. 22, 2009).

2 U.N. Office on Drugs and Crime, supra note 1.

3 Special Recommendation IX on cash couriers was adopted by the Financial Action Task Force in October 2004. See Press Release, FATF, FATF Targets Cross-Border Cash Movements by Terrorists and Criminals, (Oct. 22, 2004), available at http://www.fatfgafi.org/dataoecd/8/5/34301987.pdf.

4 Financial Action Task Force, Trade Based Money Laundering at i (June 23, 2006), available at http://www.fatf-gafi.org/dataoecd/60/25/37038272.pdf [hereinafter Trade Based Money Laundering].

5 Id.

6 Id.

7 Financial Action Task Force, Best Practices Paper on Trade Based Money Laundering (June 20, 2008), available at http://www.fatf-gafi.org/dataoecd/9/28/40936081.pdf [hereinafter Best Practices Paper].

8 Id. at 1. See also Trade Based Money Laundering, supra note 4, at 1.

9 Best Practices Paper, supra note 7, at 1-2. See also Trade Based Money Laundering, supra note 4 , at 3 . The other two definitions of TBML are the use of the financial system and 
TBML can be accomplished in a variety of ways and commonly occurs through the deliberate misrepresentation of the price, quantity, or quality of traded goods. ${ }^{11}$ TBML techniques display a wide range of complexity, from simple fraudulent invoicing to the sophisticated integration of the trade in goods into complicated financial transactions that obscure the source of funds. $^{12}$

With the more traditional avenues of money laundering being increasingly scrutinized, criminals attempting to hide the proceeds of their crimes are turning to other methods of money laundering, including activity in real estate as well as TBML. ${ }^{13}$ The stakes are rising as well-TBML may involve not only predicate crimes, ${ }^{14}$ such as narcotics trafficking, human trafficking and terrorist financing, but may also disguise the logistical support for terrorist activities, such as the movement of weapons of mass destruction and the materials used to make them. ${ }^{15}$

Each year, more than twenty million containers enter the U.S. by sea, rail and truck, from foreign countries, including those with porous law enforcement and regulatory regimes. ${ }^{16}$ Of those twenty million containers entering the U.S. annually, fewer than five percent are physically in-

the physical movement of money across international borders (e.g., through the use of cash couriers). Id. at i.

10 See Best Practices Paper, supra note 7, at 1; Trade Based Money Laundering, supra note 4 , at $13-15$.

11 Best Practices Paper, supra note 7, at 1; Trade Based Money Laundering, supra note 4, at 3-4.

12 Trade Based Money Laundering, supra note 4, at 25.

13 See, e.g., Norma J. Williams, 2007 Update ON THE USA PATRIOT ACT AND ExeCUTIVE ORDER 13224 61-62 (Williams \& Associates 2007) (noting that the U.S. Department of the Treasury's Financial Crimes Enforcement Network has found property management, real estate investment, real estate brokerage, and real estate development companies the most commonly reported entities involved with money laundering). See also Elizabeth A. Cheney, Leaving No Loopholes for Terrorist Financing: The Implementation of the USA PATRIOT Act in the Real Estate Field, 58 VAND. L. REV. 1705, 1721 (2005); Trade Based Money Laundering, supra note 4, at 1 ("Not surprisingly, research has shown that when governments take action against certain methods of money laundering or terrorist financing, criminal activities tend to migrate to other methods.").

14 Under U.S. law, the underlying crimes to the offense of money laundering are called "specified unlawful activities." 18 U.S.C. § 1956(c)(7) (2000).

15 See The Wolfsberg Group, The Wolfsberg Trade Finance Principles 1, 5-6 (Jan. 14, 2009), available at http://www.wolfsberg-principles.com. See also Oxford Analytica, Ship Containers, Potentially Used by Terrorists, May Get More Screening, THE HILL, Dec. 4, 2007, http://thehill.com/op-eds/ship-containers-potentially-used-by-terrorists-may-get-morescreening-2007-12-04.html.

16 See U.S. Customs And Border Patrol, Container Security Initiative 2006-2011 STRATEGIC PLAN 6 (2006), available at http://cbp.gov/linkhandler/cgov/trade/cargo_securi ty/csi/csi_strategic_plan.ctt/csi_strategic_plan.pdf [hereinafter CONTAINER SECURITY INITIATIVE]. 
spected. ${ }^{17}$ Consequently, this is not just a matter of combating money laundering and terrorist financing, but also of combating terrorism itself and the threats it poses to our national security.

Whether the FATF will add a forty-first Recommendation to its current 40 (40 Recommendations) ${ }^{18}$ or a tenth Recommendation to the 9 Special Recommendations on Terrorist Financing (9 Special Recommendations; collectively the $40+9$ Recommendations), ${ }^{19}$ has yet to be announced. ${ }^{20}$ Moreover, what an additional Recommendation might look like is also unknown. But in order for any new Recommendation to be effective, the FATF needs to go further than it has in the past.

Any new Recommendation on TBML should encompass not only the financial institutions and designated non-financial businesses and professions (DNFBP) currently addressed in the $40+9$ Recommendations,${ }^{21}$ but also all those involved in the international trade supply chain. This includes importers and exporters, freight forwarders, shippers, and air courierscompanies referred to as "traders" in the Best Practices Paper. ${ }^{22}$ And because most of the largest multinational industrial companies also fall within the definition of "traders," an effective TBML proposal would need to encompass a whole new category of non-financial companies that currently may not be paying close attention to the AML/CFT safeguards embodied in the $40+9$ Recommendations.

17 See Susan E. Martonosi, David S. Ortiz, Henry H. Willis, Evaluating the Viability of 100 percent container inspection at America's Ports, in THE ECONOMIC IMPACTS OF TERrorist AtTACKS 218, 221-222 Harry W. Richardson et al. eds., 2007) (citing the five percent figure).

18 Financial Action Task Force, The Forty Recommendations (June 20, 2003 \& Supp. Oct. 22, 2004), available at http://www.fatf-gafi.org/dataoecd/7/40/34849567.PDF [hereinafter Forty Recommendations].

19 Financial Action Task Force, Special Recommendations on Terrorist Financing (Oct. 22, 2004), available at http://www.fatf-gafi.org/dataoecd/8/17/34849466.pdf [hereinafter 9 Special Recommendations].

20 The 40 Recommendations are individually identified through the use of Arabic numerals (e.g., 1, 2, 3), while the Special 9 Recommendations by Roman numerals (e.g., I, II, III).

21 Designated non-financial businesses and professions cover five categories of businesses and professionals: lawyers, notaries and accountants when engaged in commercial transactions for clients; dealers in precious metals and precious stones; gambling casinos; real estate agents; and company and trust service providers when engaged in a range of services. Forty Recommendations, supra note 18, at 6-8; Financial Action Task Force, 40 Recommendations Glossary, http://www.fatfgafi.org/glossary/0,3414,en_32250379_32236889_35433764_1_1_ 1_1,00.html (last visited Fed. 1, 2009).

${ }^{22} \quad$ Best Practices Paper, supra note 7, at 2 ("The term trader refers to anyone who facilitates the exchange of goods and related services across national borders, international boundaries or territories. This would also include a corporation or other business unit organized and operated principally for the purpose of importing or exporting goods and services (e.g. import/export companies)."). 
If adopted, a new Recommendation should require governments to ensure, among other things, that traders adopt a customer identification program, conduct customer due diligence, increase the scope and quality of record keeping, and file suspicious activity reports or suspicious transaction reports, just as financial institutions and DNFBP must do under current AML/CFT standards. In the United States, this would include the four pillars of an AML program under Section 352 of the Uniting and Strengthening America by Providing Appropriate Tools Required to Intercept and Obstruct Terrorism Act (USA PATRIOT Act): (1) internal policies, procedures, and controls; (2) designation of an AML compliance officer; (3) ongoing employee training; and (4) an independent audit function to test the AML program. ${ }^{23}$

In order to demonstrate that a TBML Recommendation that imposes new obligations on traders should be added to the $40+9$ Recommendations, this article will first highlight the ability of soft law to generate effective coordination in banking and financial issues. From there, the focus will shift to the FATF Recommendations in order to show that the object and purpose of the $\mathrm{FATF}^{24}$ encompasses efforts to stop TBML. Finally, this article will discuss compliance programs designed to reduce liability for TBML, both under existing AML/CFT laws and regulations, as well as under a new FATF Recommendation or other international action on TBML.

\section{THE USE OF SOFT LAW IN THE INTERNATIONAL SPHERE TO COORDINATE FINANCE AND BANKING REGULATION}

International efforts to coordinate finance and banking regulation rely overwhelmingly on the use of soft law to generate common policies. ${ }^{25}$ The use of lex ferenda, as opposed to lex lata, ${ }^{26}$ serves several important functions in achieving the desired result of international coordination. Among these functions are speed, flexibility, and simplicity. ${ }^{27}$

23 Uniting and Strengthening America by Providing Appropriate Tools Required to Intercept and Obstruct Terrorism (USA PATRIOT) Act of 2001, Pub, L. No. 107-57, § 352, 115 Stat. 272 (2001) (codified as amended at 31 U.S.C. § 5318(h) (2001)).

24 See Vienna Convention on the Law of Treaties, art. 31, May 23, 1969, 8. I.L.M. 679 (stating that a treaty is to be interpreted in accordance with the ordinary meaning of the terms of the treaty in light of its object and purpose).

25 See generally, Martin Marcussen, OECD Governance Through Soft Law, in SofT LAw In Governance AND REgulation 103, 110 (Ulrika Mörth, ed., 2004) (noting the Organization for Economic Cooperation and Development's six-to-one preference for soft law instruments).

26 The "law as it should be," as opposed to the "law as it exists."

27 See Charles Lipson, Why Are Some Agreements Informal? 45 InT'L ORG. 495, 501 (1991) (discussing how the benefits of choosing informal agreements include avoiding formal pledges, avoiding ratification, being able to modify as circumstances change, and being able to reach agreements quickly). 
Because soft law contains neither explicit remedies nor binding enforcement mechanisms, ${ }^{28}$ in areas of common concern, soft law can be more quickly and easily developed than agreements that impose specific sanctions for violations of particular provisions. ${ }^{29}$ Furthermore, the lack of explicit remedies or enforcement mechanisms makes soft law particularly wellsuited to generate common policies in areas of complex national regulation or new and emerging issues. ${ }^{30}$

For new and emerging issues such as money laundering, ${ }^{31}$ the lack of specific sanctions in soft law can be an asset. ${ }^{32}$ Because soft law avoids recourse to litigation over non-compliance, the language and content of soft law provisions do not require the same degree of consensus as hard law $;^{33}$ in other words, crafting soft law permits a degree of speed and flexibility unusual for internationally enforceable agreements such as the 1988 Vienna Convention. As a result, soft law allows states to address new and emerging issues while "provid[ing] an opportunity for experience and experiment," which in turn encourages the flow of information among the parties in order to better address the issue and coordinate in the future. ${ }^{34}$

For issues that already receive national treatment in virtually every country, such as the basic elements of bank regulatory law, both the public and private sectors understandably are reluctant to add another layer of specifically enforceable measures onto an already burdensome and often byzantine system of regulation. ${ }^{35}$ By relying on soft law to set international standards for national efforts, the overall aim can be achieved, e.g., the criminalization of money laundering, while the methods by which this goal is

28 JOSEPH GOLD, INTERPRETATION: THE IMF AND INTERNATIONAL LAW 301 (1996) ("Soft law expresses a preference and not an obligation that states should act, or should refrain from acting, in a specified manner. The underlying assumption is that behavior, or forbearance from behavior, in accordance with this preference will be directly beneficial to states.").

29 See Lipson, supra note 27, at 501 (discussing the benefits of using informal agreements).

30 See Dinah Shelton, Law, Non-Law and the Problem of 'Soft Law,' in COMmitMENT AND Compliance: The Role of Non-Binding Norms in the International Legal System 13 , 14 (Dinah Shelton ed., 2000).

31 The 40 Recommendations were first issued in 1990. Forty Recommendations, supra note 18 , at $\mathrm{i}$.

32 David A. Wirth, Compliance with Non-Binding Norms of Trade and Finance, in COMMITMENT AND COMPLIANCE: THE ROLE OF NON-BINDING NORMS IN THE INTERNATIONAL LEGAL SySTEM 330, 330 (Dinah Shelton ed., 2000) (“'A] non-binding 'soft' instrument can allow [states] to gain experience with more ambitious, aspirational goals in a less risky milieu.").

33 GolD, supra note 28, at 301 ("In other instances, soft law is all that can be achieved because adequate experience to support firm law is thought to be missing.").

34 Shelton, supra note 30 , at 15.

35 Id. at 14 
accomplished remain open. As such, "compliance may be improved by increasing opportunities to engage in desirable behavior."

Furthermore, soft law can increase the involvement of non-state actors. "I7 "In the area of trade and finance, where the private sector predominates and is the primary target of norms, non-binding instruments, despite their non-binding character, become appealing vehicles through which states can establish expectations." 38

Consequently, for an issue such as TBML, which involves both trade and finance and needs to involve a variety of non-state actors, the FATF 40+9 Recommendations can take advantage of the flexibility and range found in soft law instruments to great effect. And although a soft law instrument would preclude certain enforcement efforts that hard law would allow, soft law has been the vehicle of choice in international banking law and has been employed with increasing effect over the last thirty years. ${ }^{39}$

\section{A. International Banking Law: The Utility of Soft Law}

Because banks take deposits from the public and are universally subject to a plethora of rules generated by their regulators, ${ }^{40}$ banking issues are well suited to soft law in the international sphere.

Despite the non-binding nature of soft law, it "is entered into with the expectation shared by all parties that they will observe it." ${ }^{, 11}$ The international standards concerning banking from the Bank for International Settlements $(\mathrm{BIS})^{42}$ provide a clear example of this expectation of compliance.

As a leading actor in international banking standards, the BIS and its Committees, particularly the Basel Committee on Banking Supervision, operate almost exclusively through soft law instruments. And although the

36 Id. at 15.

37 Wirth, supra note 32 , at 331.

38 Id.

39 See Michael P. Malloy, International Banking 77 et seq. (2d ed., Carolina Acad. Press 2005). See also Part III.A.2, infra.

40 For example. in the U.S., there are five Federal banking regulators: the Board of Governors of the Federal Reserve-which regulates state member banks and bank and financial holding companies, the Office of the Comptroller of the Currency-which regulates national banks, the Office of Thrift Supervision-which regulates savings associations and savings and loan holding companies, the Federal Deposit Insurance Corporation-which regulates state non-member banks, including industrial loan companies, and the National Credit Union Administration - which regulates Federal credit unions. State-chartered banks are additionally regulated by authorities of the chartering state.

41 GoLD, supra note 28, at 301-302.

42 "The Bank for International Settlements is an international organization [headquartered in Basel, Switzerland, that] which fosters international Monetary and financial cooperation and serves as a bank for central banks." About the Bank for International Settlements, http://www.bis.org/about/index.htm. (last visited, Feb. 2, 2009). 
BIS does not have formal regulatory authority, the BIS's Basel Capital Accord, for example, "is considered to be binding on the members and the agreement itself states that the Committee will continually monitor its application." 43 As another example, the BIS's 1992 Report on Minimum Standards for Capital Adequacy explicitly that states that it is non-binding ${ }^{44}$ but also explicitly states that BIS participants are expected to implement the standards contained therein, and that BIS participants may undertake action to minimize the risks associated with noncompliance. ${ }^{45}$

The more recent BIS Accord, Basel II, ${ }^{46}$ has broadened the impact of BIS soft law. "More importantly, states have endorsed the specific principles of the [Basel II] Accord as legally binding features of their national regulatory systems, and the states - and affected private sectors-have treated the development of Basel II as legally significant." ${ }^{, 47}$ Many features of both the U.S. and European Union bank regulatory regimes reflect standards that match or exceed those issued by the BIS and its Committees. ${ }^{48}$ Furthermore, those financial authorities not adhering to BIS standards "risk being regarded by major international banks and their financial authorities, including BIS itself, as 'unattractive' business partners. And in this global economy they cannot afford to develop activities in isolation." 49

\section{INTERNATIONAL EFFORTS REGARDING ANTI-MONEY LAUNDERING AND COMBATING THE FINANCING OF TERRORISM: THE HARDEST KIND OF SOFT LAW}

When a new issue like AML/CFT emerges internationally, soft law facilitates the quick and coordinated effort needed to address the problem. Taking advantage of its flexibility and speed, soft law has been the major

43 Peter C. Hayward, Prospects for International Cooperation by Bank Supervisors, 24 INT'L LAW. 787, 790-91 (1990).

44 See Michael P. Malloy, Emerging International Regime of Financial Services Regulation, 18 TRANSNAT'L LAW. 329, 346 (2005).

45 See id. (concluding that "[i]ndeed, in U.S. practice the fourth standard has been implemented as a statutory expectation and requires that a non-U.S. based banking enterprise applying for entry will be subject to comprehensive supervision by its home state as a condition of entry into the U.S. market.").

46 Bank for International Settlements, Basel Committee on Banking Supervision, International Convergence of Capital Measurement and Capital Standards, A Revised Framework (June 2004), available at http://www.bis.org/publ/bcbs107.pdf.

47 Malloy, supra note 44, at 346.

48 See Michael P. Malloy, International Banking 77 et seq. (2d ed., Carolina Acad. Press 2005).

49 Carl Felsenfeld \& Genci Bilali, The Role for the Bank of International Settlements in Shaping the World Financial System, 25 U. PA. J. INT'L ECON. L. 945, 991-92 (2004). 
vehicle through which states have coordinated their AML/CFT efforts internationally. ${ }^{50}$

The leading international organization dedicated to setting standards in the field of AML/CFT is the FATF. Although now an independent organization with a finite but renewable mandate, the FATF was created at a 1989 G-7 meeting under the auspices of the Organisation for Economic Cooperation and Development ${ }^{51}$ to address international money laundering undertaken by transnational organized crime groups. ${ }^{52}$

To this end, the FATF first issued its 40 Recommendations in $1990,{ }^{53}$ initially revised them in $1996,{ }^{54}$ and then revised them again in $2003 .^{55}$ The 40 Recommendations demonstrate both the flexibility and effectiveness of soft law in generating international action on combating money laundering. ${ }^{56}$ With the October 2001 issuance of the 8 Special Recommendations on Terrorist Financing (now 9 Special Recommendations,

50 Most international instruments on money laundering have a non-binding and flexible character. Id. But see U.N. Convention Against Illicit Traffic in Narcotic Drugs and Psychotropic Substances, Dec. 20, 1988, 1582 U.N.T.S. 165, 170 [hereinafter the 1988 Vienna Convention]; U.N. Convention Against Transnational Organized Crime, Dec. 12, 2000, 2225 U.N.T.S. 209, 277 [hereinafter Palermo Convention]. The 1988 Vienna Convention requires signatory nations to criminalize the laundering of drug money. The 1988 Vienna Convention, supra, art. 3. The Palermo Convention requires signatory nations to criminalize money laundering for "the widest range of predicate offenses" and requires signatories to set up a "comprehensive" domestic regime to combat money laundering including customer identification and suspicious activity reporting. Palermo Convention, supra, arts. 6-7. See also Beth Simmons, International Efforts Against Money Laundering, in COMMITMENT AND CoMPLIANCE: The Role of Non-Binding Norms IN THE INTERNATIONAL LEGAL SySTEM 244, 250-54 (Dinah Shelton ed., 2000) (noting that, at the time of publication in 2000, nine of the ten international instruments combating money laundering are soft law, with the exception being the 1988 Vienna Convention).

51 The OECD headquarters in Paris, France houses the FATF secretariat. See Organisation for Economic Co-operation and Development, OECD Departments, Directories, Centres and Agencies, http://www.oecd.org/maindepartment/0,3350,en_2649_201185_1_1_1_1_1,00. html (last visited Feb. 1, 2009).

52 Financial Action Task Force, FATF Revised Mandate (April 12, 2008), available at http://www.fatf-gafi.org/dataoecd/3/32/40433653.pdf [hereinafter Revised Mandate].

53 See Financial Action Task Force, The Forty Recommendations, http://www.fatfgafi.org/document/28/0,3343,en_32250379_ 32236930_33658140_1_1_1_1,00.html (last visited Feb. 1, 2009).

$54 \quad I d$.

55 Id.

56 Beth Simmons, International Efforts Against Money Laundering, in COMMITMENT AND Compliance: The Role of Non-Binding Norms in the InTERnATIONAl Legal System 244, 262 (Dinah Shelton ed., 2000) ("The choice of a non-binding legal accord in the area of money laundering was a significant step toward harmonizing national rules to fight money laundering. . . . Guidelines in the form of recommendations permit countries to implement them according to their particular circumstances, in contrast to mandatory detailed obligations in a binding document."). 
collectively the $40+9$ Recommendations $)^{57}$ in the aftermath of the events of September 11, 2001, the FATF added a second set of standards, this time relating to CFT, in addition to its original standards on AML.

Consistent with OECD practice, the 40+9 Recommendations rely on information gathering, mutual monitoring, and "name and shame" sanctions in order to accomplish its goals. ${ }^{58}$ Addressing both states and non-state actors, such as financial institutions and certain "gatekeepers" ${ }^{59}$ known as designated non-financial businesses and professions (DNFBP), the 40+9 Recommendations call upon states to, inter alia: (1) criminalize and penalize money laundering and the financing of terrorism; ${ }^{60}(2)$ require customer due diligence and record keeping by financial institutions and DNFBP; ${ }^{61}(3)$ require the reporting of suspicious transactions and other similar measures; $^{62}$ (4) provide for sanctions against non-compliant states; ${ }^{63}(5)$ create and maintain competent authorities to prevent money laundering, including law enforcement; (6) supervise financial institutions and DNFBP; ${ }^{64}$ and (7) engage in greater international cooperation. ${ }^{65}$

57 Forty Recommendations, supra note 18, at i. Special Recommendation IX, on cash couriers, was added by the FATF in October 2004. See 9 Special Recommendations, supra note 19 , at 2 .

58 Michael Levi \& Peter Reuter, Money Laundering, 34 CRIME \& JUST. 289, 306 (2006). See also Martin Marcussen, OECD Governance Through Soft Law, in SoFT LAW IN GovernanCE AND REgulation 103, 103 (Ulrika Mörth, ed., 2004) (quoting OECD leaders characterizing OECD efforts as a "continuing process of consultation" and "enforcement through peer pressure").

59 Designated non-financial businesses and professions were described earlier in this article. See supra note 21. See also Forty Recommendations, supra note 18, q币 16-24; Financial Action Task Force, Interpretative Notes to the 40 Recommendations of the FATF (October 22, 2003), http://www.fatfgafi.org/document/28/0,3343,en_32250379_32236920_33

988956_1_1_1_1,00.html; Financial Action Task Force, 40 Recommendations Glossary, http://www.fatfgafi.org/glossary/0,3414,en_32250379_32236889_35433764_1_1_1_1,00.ht $\mathrm{ml}$ (last visited Feb. 1, 2009).

60 Recommendations 1, through 3, 17, 38, 39 and Special Recommendations I-III and IX. Forty Recommendations, supra note 18, at 1-2.

61 Recommendations 4-12 and 20. Id. at 2-5.

62 Recommendations 13, 14, 16, 19, 20 and Special Recommendation IV. Id. at 5-7.

63 Recommendation 21. Id. at 7-8.

64 Recommendations 23-27, $29-31$. Id. at 8-9.

65 Recommendations 35-37, 40 and Special Recommendation V. Id. at 9-11. Several other sources are available to give an overview of the content of the 40 Recommendations. See, e.g., Herbert V. Morais, Fighting International Crime and its Financing: The Importance of Following a Coherent Strategy based on the Rule of Law, 50 VILL. L. REV. 583, 596-603 (2005). 


\section{A. Compliance with the Financial Action Task Force's Recommenda- tions on Soft Law}

Despite the nonbinding nature of the $40+9$ Recommendations, ${ }^{66}$ by the year 2000, all but one FATF member had undertaken efforts to facilitate mutual legal assistance for investigations, ${ }^{67}$ all but two FATF members required specific AML programs-including activity reporting, ${ }^{68}$ and nearly all FATF members had enacted measures for customer identification. ${ }^{69}$

Furthermore, the 40 Recommendations impacted states and private enterprise beyond the actual membership of the FATF. ${ }^{70}$ Starting in February 2000 , the FATF began publishing a series of reports identifying countries that failed to meet the 40 Recommendations and placed them on a list of Non-Cooperative Countries and Territories (the NCCT List). ${ }^{71}$ The initial "name and shame" list contained fifteen jurisdictions. ${ }^{72}$ Between the publication of the first list in June 2000 and the removal in October 2006 of Myanmar, the last country on the list, all fifteen original jurisdictions had gone through a process of strengthening their legal and institutional frameworks to avoid the stigma associated with membership on the NCCT List. $^{73}$ Currently, no countries remain on the list.

\footnotetext{
66 Beth Simmons, International Efforts Against Money Laundering, in COMMITMENT AND Compliance: The Role of Non-Binding Norms in the InTERnational Legal System 244, 245 (Dinah Shelton ed., 2000).

67 Id. at 257.

68 Id.

$69 \quad I d$.

70 A list of member states is available online. Financial Action Task Force, FATF Members and Observers, http://www.fatf-gafi.org/document/52/0,3343,en_32250379_32237295 34027188_1_1_1_1,00.html (last visited Feb. 23, 2009).

${ }_{71}$ See FATF press release, available at http://www.fatf-gafi.org/dataoecd/58/52/357182 02.pdf.

72 The original fifteen countries were: Bahamas, Cayman Islands, Cook Islands, Dominica, Israel, Lebanon, Liechtenstein, Marshall Islands, Nauru, Niue, Panama, Philippines, the Russian Federation, St. Kitts and Nevis, and St. Vincent and the Grenadines. See Press Release, FATF, 1999-2000 Report Released (June 22, 2000), available at http://www.fatfgafi.org/dataoecd/58/28/35717473.pdf.

73 Financial Action Task Force, Annual Review of Non-Cooperative Countries and Territories 2006-2007: Eighth NCCT Review, at 13 (Oct. 12, 2007), available at http://www.fatfgafi.org/dataoecd/14/11/39552632.pdf.
} 
1. Current initiatives by Financial Action Task Force, FATF-Style Regional Bodies (FSRBs), the International Monetary Fund (IMF), and the World Bank to promote compliance with the FATF Recommendations

Beginning in 1992, the FATF began a process of conducting periodic mutual evaluations of its members, circulating mutual evaluation reports to all FATF members and publishing executive summaries in the FATF annual report. ${ }^{74}$ That process became more formalized in October 2002, when the FATF, FSRBs, the International Monetary Fund (IMF), and the World Bank cooperated to draft what is now called the "Methodology for Assessing Compliance with the FATF 40 Recommendations and the FATF 9 Special Recommendations" (the Methodology). "[T]he Methodology is a key tool to assist assessors in . . . identifying the systems and mechanisms developed by countries with diverse legal, regulatory and financial frameworks, in order to implement robust AML/CFT systems."76 The Methodology is currently used not only by the FATF and FSRBs in their mutual evaluations of members, but also by the IMF and World Bank in assessments of their member countries, as well as of offshore financial centers often affiliated with FATF member countries. ${ }^{77}$

The goal of the evaluation/assessment process is to determine whether the AML/CFT framework is effective:

An effective AML/CFT system requires an adequate legal and institutional framework, which should include: (i) laws that create money laundering (ML) and terrorist financing (FT) offences and provide for the freezing, seizing and confiscation of the proceeds of crime and terrorist funding; (ii) laws, regulations or in certain circumstances other enforceable means that impose the required obligations on financial institutions and designated non-financial businesses and professions; (iii) an appropriate institutional or administrative framework, and laws that provide competent authorities with the necessary duties, powers and sanctions; and (iv) laws and other measures that give a country the ability to provide the widest range of in-

74 Financial Action Task Force, Financial Action Task Force on Money Laundering Annual Report 1991-1992, at paras. 29-53 (June 25, 1992), available at http:/www.fatfgafi.org/dataoecd/31/19/34041197.pdf (France, Sweden, the United Kingdom, and Australia were the first countries to undergo a mutual evaluation).

75 Financial Action Task Force, Methodology for Assessing Compliance with the FATF 40 Recommendations and the FATF 9 Special Recommendations, at 1 (updated Feb. 2009), available at $\mathrm{http}: / / \mathrm{www}$.fatf-gafi.org/dataoecd/16/54/40339628.pdf.

76 Id.

77 Id. at 5. 
ternational co-operation. It is also essential that the competent authorities ensure that the whole system is effectively implemented. ${ }^{78}$

The process by which the FATF and FSRB mutual evaluations and the IMF and World Bank assessments are prepared has had the practical effect of pressuring countries to adhere to the $40+9$ Recommendations, principally through the publication of ratings of individual FATF Recommendations that are part of every evaluation/assessment. ${ }^{79}$ While publication of the reports is voluntary, it is rare for a country to refuse to do so. As a result, ratings of the $40+9$ Recommendations routinely become public, as do recommendations for improvement of the country's AML/CFT framework. ${ }^{80}$ This creates both a mandate for change in each country as well as heightened scrutiny from FATF members, particularly the G-7, to adhere to FATF standards.

\section{Seychelles' Economic Development Act: A brief case study}

The FATF's response to the Economic Development Act of the Seychelles provides a clear case of the effectiveness of the FATF in achieving its goals through soft law. In 1995, the Seychelles, a small archipelago in the Indian Ocean, passed its Economic Development Act (EDA), which was ostensibly designed to attract investment into the islands. ${ }^{81}$ The EDA provided that any investor investing over $\$ 10,000,000$ in certain projects on the islands would receive immunity for any violent or drug-related crimes in the Seychelles. ${ }^{82}$

Using the "name and shame" sanctions at its disposal, ${ }^{83}$ the FATF publicized the Seychelles law, and called upon its members to "closely scru-

$78 \quad$ Id. at 6.

79 Recommendations 21 and 22 of the 40 Recommendations, provide sanctions based on a "name and shame" principle ranging from letters of warning to diplomatic missions and calls for action to its members. See Beth Simmons, International Efforts Against Money Laundering, in COMmitment AND COMPliance: THE ROLE OF NON-BINDING NoRMS IN THE INTERNATIONAL LEGAL SySTEM 244, 255-58 (Dinah Shelton ed., 2000) (calling FATF sanctions "a graduated system of embarrassment through peer pressure").

80 See Financial Action Task Force, Publications, http://www.fatf-gafi.org/pages/0,3417, en_32250379_32237235_1_1_1_1_1,00.html (last visited Feb. 23, 2009).

81 Seychelles Abolishes EDA, ILS FIDUCIARIES NEWSLETTER, http://www.ilsworld.com/newsletter/archive/seychelles.shtml (last visited Dec. 21, 2008).

82 Id.

83 Under Recommendations 21 and 22, FATF sanctions compose a rely on the "name and shame" principle, with sanctions ranging from letters of warning to diplomatic missions and calls for action to its members. See Beth Simmons, International Efforts Against Money Laundering, in Commitment and Compliance: The Role of Non-Binding Norms IN THE INTERNATIONAL LEGAL SYSTEM 257 (Dinah Shelton ed., 2000) (calling FATF sanctions "a graduated system of embarrassment through peer pressure"). 
tinize" all activity with Seychelles, which is not a FATF member. ${ }^{84}$ On July 25,2000 , the Seychelles legislature repealed the EDA, ${ }^{85}$ and affirmed its commitment to the fight against money laundering. ${ }^{86}$ The FATF ceased the application of Recommendation 21 sanctions on October 11, 2000. ${ }^{87}$

\section{B. $\quad$ Trade-Based Money Laundering: The Forty-first Recommendation or the Tenth Special Recommendation on Terrorist Financing?}

A new Recommendation on TBML would fit squarely within the FATF mandate. ${ }^{88}$ As transactions involving the more traditional avenues of money laundering are scrutinized, detected and monitored, criminals will move to alternate methods of laundering the profits of their crimes and financing their organizations. ${ }^{89}$

84 See Beth Simmons, International Efforts Against Money Laundering, in COMMITMENT AND COMPliance: THE Role of NON-BINDING NORMS IN THE INTERNATIONAL LEGAL System 244, 258-59 (Dinah Shelton ed., 2000).

${ }^{85}$ FATF Lifts Its Investment Warning About Investment Law in Seychelles, ORGANISATION FOR ECONOMIC CO-OPERATION AND DEVELOPMENT, Oct. 11, 2000, http://www.oecd.org/dataoecd/57/60/35714451.pdf.

${ }^{86}$ Lisa Ugur, Seychelles Underlines Tough Stance on Money Laundering with New UN Treaty, TAX-NEws.Com Dec. 14, 2000, http://www.tax-news.com/archive/story/Seychelles _Underlines_Tough_Stance_On_Money_Laundering_With_New_UN_Treaty_xxxx1495. html.

87 FATF Lifts Its Investment Warning About Investment Law in Seychelles, ORGANISATION FOR ECONOMIC CO-OPERATION AND DEVELOPMENT, Oct. 11, 2000, http://www.oecd.org/dataoecd/57/60/35714451.pdf.

${ }^{88}$ Revised Mandate, supra note 52, at 2 ("The FATF, since its establishment, has focused its work on three main activities: standard setting, ensuring effective compliance with the standards and identifying money laundering and[, since 2001,] terrorist financing threats. These activities will remain at the core of the FATF's work for the remainder of this mandate. Going forward, the FATF will build on this work and respond to new and emerging threats, such as proliferation financing and vulnerabilities in new technologies which could destabilize the international financial system.").

89 Herbert V. Morais, Fighting International Crime and its Financing: The Importance of Following a Coherent Strategy based on the Rule of Law, 50 VILL. L. REV. 583, 619 (2005) ("As legal measures and law enforcement efforts worldwide continue to tighten the noose around money launderers, terrorists and corrupt public officials, criminals have shown remarkable determination and ingenuity in devising new methods and schemes to launder criminal proceeds or finance terrorist activities over and above the traditional laundering techniques using the formal banking system."). See also Cheney, supra note 13; WiLliams, supra note 13, at 61-62 (noting that the U.S. Department of the Treasury's Financial Crimes Enforcement Network has found property management, real estate investment, real estate brokerage, and real estate development companies the most commonly reported entities involved with money laundering). See also Trade Based Money Laundering, supra note 4, at 1 ("Not surprisingly, research has shown that when governments take action against certain methods of money laundering or terrorist financing, criminal activities tend to migrate to other methods."). 
With twenty million containers entering into the U.S. in 2005, a number expected to triple by $2020,{ }^{90}$ and with less than five percent of those containers being physically inspected, ${ }^{91}$ the international trade system remains an attractive avenue for those wishing to launder the proceeds of a crime or engage in the financing of terrorism. ${ }^{92}$ As noted by Stephen Flynn, former National Guard Commander and senior fellow at the Council on Foreign Relations, "[t]he bad guys know how open the system is. The good guys do not seem to have a real command on it here because we have not paid as much attention to this problem as we need to." $" 93$

Through its monitoring of money laundering typologies, the FATF has identified international trade as one of the three major avenues for money laundering and terrorist financing. ${ }^{94}$ Yet international trade has received relatively little attention over the life of the FATF. The other two avenues, abuse of the financial system and the physical movement of cash across international borders, already are well covered by the $40+9$ Recommendations. ${ }^{95}$ But "[i]nherent vulnerabilities in the international trade system, including the enormous volumes of trade flows, which obscures individual transactions, provide abundant opportunity for criminal organizations and terrorist groups to transfer value across borders." 96

Additionally, the FATF has recognized that the increasing scrutiny of the other two major avenues, financial instruments and cash smuggling, "may have the unintended effect of increasing the attractiveness of interna-

90 See CONTAINER SECURITy InItIATIVE, supra note 16 , at 12.

91 Susan Martonosi, David S. Ortiz \& Henry H. Willis, Evaluating the Viability of 100 per cent container inspection at America's Ports, in THE ECONOMIC IMPACTS OF TERRORIST ATTACKs 218, 222 (Harry W. Richardson et al. eds., 2005). But see C.J. Karamargin, Kolbe: Real Ports Issue is Container Inspection, ARIz. DAILy STAR, March 9, 2006, at A7 (citing a one percent figure); Peter J. Kaye, Keep an Eye on Your Supply Chain, 78 PENN. CPA J. 32 (2007) (citing a two percent figure). Although the U.S. Customs and Border Protection maintains that one-hundred percent of all containers are "screened" prior to arrival, they define "screening" as a combination of actual physical inspection, $\mathrm{x}$-ray or non-intrusive inspection, and intelligence analysis designed to identify high-risk shipments. U.S. CUSTOMS AND Border Protection, Port SECURity (2006).

92 For an argument that free trade zones can exacerbate this risk, see Heather A. Brown, CAMS, Free Trade Zones: Haven for Money Laundering and Terrorist Financing?, ACAMS TODAY, Jan. 2009, at 10-12, available at http://www.acams.org/Members/Resou rceCenter/ACAMSToday/2009_January.pdf.

93 On the Waterfront, CBS NEws: 60 MinUTES, Feb. 26, 2006, http://www.cbsnews.com/ stories/2006/02/24/60minutes/main1344473.shtml (quoting interview of Stephen Flynn).

94 Trade Based Money Laundering, supra note 4, at 1. See also The Wolfsberg Group, The Wolfsberg Trade Finance Principles 3 (Jan. 14, 2009), available at http://www.wolfsbergprinciples.com (listing general typologies, including over- and under-invoicing and shipping).

95 Id.

96 Best Practices Paper, supra note 7, at 1. 
tional trade system for money laundering and terrorist financing activities." $" 97$

\section{Fit as the 41st Recommendation}

The international fight against money laundering began with a focus on illegal narcotics. ${ }^{98}$ One of the first multilateral initiatives on the need to combat money laundering came from the BIS ${ }^{99}$ in December 1988, when it issued its soft law "Statement of Principles on the Prevention of the Criminal Use of the Banking System for the Purposes of Money Laundering" (BIS Principles). ${ }^{100}$ In the preamble, the BIS states that "the increasing international dimension of organized criminal activity, notably in relation to the narcotics trade, has prompted collaborative initiatives at the international level." 101

Negotiated at the same time as the BIS Principles was the hard law Vienna Convention Against Illicit Traffic in Narcotic Drugs and Psychotropic Substances, which was opened for signature in December 1988, and entered into force in November $1990 .{ }^{102}$ The 1988 Vienna Convention required all signatory countries to criminalize the laundering of drug profits. ${ }^{103}$ Moreover, when the FATF issued its first annual report in 1990, it noted that the 1988 Vienna Convention's creation by the G-7 was because "the drug problem ha[d] reached devastating proportions," and the resolution creating it was passed "among other resolutions on drug issues." 104

97 Trade Based Money Laundering, supra note 4, at 1.

98 The first statutes defining money laundering crimes were enacted in the U.S. and came into existence with the Money Laundering Control Act of 1986, which was part of the AntiDrug Abuse Act of 1986. See Money Laundering Control Act of 1986, Pub. L. No. 99-570, 100 Stat. 3207 (codified as amended at 18 U.S.C. $\S \S 1956-1957$ (2000)). See also Beth Simmons, International Efforts Against Money Laundering, in COMMITMENT AND COMPliance: The Role of Non-Binding Norms In the INTERNATIONAL LEgAL SySTEM 244, 246 (Dinah Shelton ed., 2000) ("In 1986, the U.S. was the only country to have criminalized money laundering."); Levi \& Reuter, supra note 58, at 306 ("For the United States, this was an important front for the war on drugs.").

99 "The Bank for International Settlements is an international organization[, headquartered in Basel, Switzerland, that] fosters international Monetary and financial cooperation and serves as a bank for central banks." About the Bank for International Settlements, http://www.bis.org/about/index.htm (last visited Feb. 1, 2009).

100 Bank for International Settlements, Statement of Principles on the Prevention of the Criminal Use of the Banking System for the Purposes of Money Laundering, at 1 (December 1988), available at http://www.bis.org/publ/bcbsc137.pdf.

101 Id.

102 The 1988 Vienna Convention, supra note 50.

103 Id. at 170.

104 Financial Action Task Force, Financial Action Task Force on Money Laundering Report, at 3 (1990), available at http://www.fatf-gafi.org/dataoecd/20/16/33643019.pdf. 
Indeed, of the twelve case studies provided, the TBML Report specifically identified four instances of TBML by transnational drug cartels. ${ }^{105}$ Additionally, the FATF acknowledges that " $[\mathrm{t}]$ he original 40 Recommendations were drawn up in 1990 as an initiative to combat the misuse of the financial system by persons laundering drug money." mandate requires it to "build upon [its previous] work and respond to new and emerging threats," a 41st Recommendation on TBML would fit squarely within the FATF's original object and purpose of responding to the threat of money laundering posed by the international trade in drugs, and also its current expanded mandate. ${ }^{107}$

2. Fit as the tenth Special Recommendation on combating the financing of terrorism

On the other hand, a tenth Special Recommendation on TBML would fit well with the character of the 9 Special Recommendations. ${ }^{108}$ While the original 40 Recommendations address states, financial institutions, and DNFBP ${ }^{109}$ the 9 Special Recommendations address entities and organizations not previously covered by the FATF. ${ }^{110}$

Eight of the 9 Special Recommendations were adopted at an extraordinary plenary meeting of the FATF held on October 29-30, 2001, ${ }^{11}$ following almost immediately on the heels of U.N. Security Council Resolution 1373, which focused on cutting off the sources of funds for terrorists. ${ }^{112}$ Although the language of the 9 Special Recommendations mirrors that of the original 40 Recommendations, and the 9 Special Recommendations primarily address states, three of the Special Recommendations deal with alternative remittance systems, ${ }^{113}$ money remitters, ${ }^{114}$ and non-profit organizations. ${ }^{115}$ In October 2004, Special Recommendation IX, addressing

105 Trade Based Money Laundering, supra note 4, at 13-15, 19.

106 Financial Action Task Force, Financial Action Task Force on Money Laundering Annexes 2002-2003, at 1 (2003), available at http://www.fatf-gafi.org/dataoecd/12/63/3432

8318.pdf.

107 Revised Mandate, supra note 52, at 2.

1089 Special Recommendations, supra note 19.

109 See Forty Recommendations, supra note 18, at 2-6.

110 See 9 Special Recommendations, supra note 19, at 1-2.

111 U.S. Dep't of State Bureau of Int'L Narcotics and Law EnForcement AfFairs, 2003 INT'L NARCOTICS CONTROL STRATEGY REPORT (2004), http://www.state.gov/p/inl/rls/n rcrpt/2003/vol2/html/29915.htm.

112 S.C. Res. 1373, U.N. Doc. S/RES/1373 (September 28, 2001).

113 Special Recommendation VI. 9 Special Recommendations, supra note 19.

114 Special Recommendation VII. Id.

115 This is in Special Recommendation VIII. Id. 
cash couriers, was added to address a major avenue of terrorist financing and money laundering. ${ }^{116}$

With the identification of extensive vulnerabilities in the international trade system to money laundering and terrorist financing, a tenth Special Recommendation may not be far behind the other nine. In February 2008, the FATF issued a report entitled "Terrorist Financing" (Terrorist Financing Report) that included a case study from Belgium that illustrated a real world example of TBML being used to support a terrorist organization. ${ }^{117}$

In the case study, large amounts of dollars flowed into the Belgian account of a business enterprise, and Euros flowed out to "Individual A," who resided in the Middle East. ${ }^{118}$ The large inflows were the proceeds from the sale of conflict diamonds that "Individual B" and "Individual A" had smuggled into Belgium, and authorities discovered that "Individual A" and "Individual B" intended this transaction to benefit a known terrorist organization. ${ }^{119}$

Other incidents in the Terrorist Financing Report center on the use of the international drug trade to benefit terrorist organizations. ${ }^{120}$ Case studies submitted by the U.S., the Netherlands, and Turkey describe how terrorist organizations either control or derive substantial benefit from international drug trafficking networks. ${ }^{121}$

What is most notable about these case studies is the striking similarity among the money laundering and financing techniques of international drug cartels, terrorist organizations and other transnational criminal networks. The main difference is to whom the proceeds of the illegal activity are delivered. In one case, the benefits go to a Belgian diamond trader, and in another, the benefits accrue to an international terrorist organization. Indeed, "the greatest risk" is that a company operating with integrity could, inadvertently and through the normal course of its business, be aiding "the proliferation of WMD."122 These risks in the international trade system should be addressed by those most directly involved in it, because they are

116 Financial Action Task Force, Detecting and Preventing the Cross Border Movement of Cash by Terrorists and Other Criminals: International Best Practices, at 2 (Feb. 12, 2005), available at http://www.fatf-gafi.org/dataoecd/50/63/34424128.pdf.

117 Financial Action Task Force, Terrorist Financing, at 23 (Feb. 29, 2008), available at http://www.fatf-gafi.org/dataoecd/28/43/40285899.pdf [hereinafter Terrorist Financing].

118 Id.

119 Id

120 Id. at $15-17$.

121 Id. at 16-17. See also Sara A. Carter, Hezbollah Uses Mexican Drug Routes into U.S., WAsh. TIMES, Mar. 27, 2009, at A1.

122 The Wolfsberg Group, The Wolfsberg Trade Finance Principles 5 (Jan. 14, 2009), available at $\mathrm{http}: / / \mathrm{www}$.wolfsberg-principles.com. 
best situated to develop safeguards designed to prevent this abuse of the international trade system.

\section{MEETING THE REQUiREMENTS OF A TRADE-BASED MONEY \\ LAUNDERING RECOMMENDATION: RED FLAGS AND COMPLIANCE PROGRAMS}

As its mandate was extended in 2004, the FATF acknowledged that much work remained in its counter-terrorist financing mission, and stated that a "stronger connection between the typologies exercises and the standard setting task of the FATF must be created." 123 Having recently identified TBML as one of three major avenues by which to launder proceeds of a crime, a new Recommendation on TBML would fit with either the character of the original 40 Recommendations or the 9 Special Recommendations on CFT.

Now that this risk is known and the extent of its dangers are becoming apparent, the threat of TBML may no longer be ignored by companies in the international trade supply chain - to do so exposes such businesses to potential civil and criminal liability. Consequently, what TBML is, how to spot it, and how to prevent it, have become significant issues for both the public and private sectors. Although FATF's Best Practices Paper calls for gathering more and better information to help identify "other measures that could be considered in combating illicit use of the trade system," FATF and others, in particular the five U.S. banking regulators, ${ }^{125}$ have already produced useful guidelines on reducing potential exposure to TBML.

\section{A. The Definition of Trade-Based Money Laundering}

The June 2006 TBML Report defines trade-based money laundering as the process of disguising the proceeds of crime and moving value through use of trade transactions to legitimize their illicit origins. ${ }^{126}$ This can be achieved through a variety of methods, including misrepresentation of the price, quantity, or quality of imports or exports, or by tax and/or customs fraud. The methods employed vary in complexity, and often misrepre-

\footnotetext{
123 Financial Action Task Force, Financial Action Task Force on Money Laundering Annexes 2003-2004, at 3 (2004), available at http://www.fatf-gafi.org/dataoecd/32/31/3539 6215.pdf.

124 Best Practices Paper, supra note 7, at 1, 5-7

125 See Appendix F, p. F-5, of the U.S. Federal Financial Institutions Examination COUnCIL BanK SECRecy Act/Anti-Money Laundering Examination Manual 2007 [hereinafter EXAMINATION MANUAL], available at http://www.ffiec.gov/bsa_aml_infobase/docu ments/BSA_AML_Man_2007.pdf

126 Trade Based Money Laundering, supra note 4, at 3.
} 
sentative or fraudulent documents will be a component of the scheme to launder the proceeds of criminal activity. ${ }^{127}$

Activities related to trade finance, primarily activities of banks in financing international trade, are a subset of TBML methods. These activities include issuing and confirming letters of credit for exports and imports and making loans to companies for the export or import of goods, as well as providing guarantees or stand-by letters of credit and pre-export financing, assisting companies in the collections process, discounting drafts and acceptances, and offering fee-based services such as credit and country information on buyers. ${ }^{128}$

\section{B. $\quad$ Red Flags for Trade-Based Money Laundering}

How can firms recognize trade-based money laundering well enough to form suspicions worth reporting? U.S. banking regulators and the FATF offer some clues:

(1) Items shipped that are inconsistent with the nature of the customer's business (e.g., a steel company that starts dealing in paper products, or an information technology company suddenly dealing in bulk pharmaceuticals) ${ }^{129}$

(2) Customers conducting business in high-risk jurisdictions; ${ }^{130}$

(3) Customers shipping items through high-risk jurisdictions, including transit through non-cooperative countries; ${ }^{131}$

(4) Customers involved in potentially high-risk activities, including those subject to export/import restrictions (e.g., equipment for military or police organizations of foreign governments, weapons, ammunition, chemical mixtures, classified defense articles, sensitive technical data, nuclear materials, precious gems, or certain natural resources such as metals, ore and crude oil); ${ }^{132}$

(5) Obvious over- or under-pricing of goods and services; ${ }^{133}$

(6) Obvious misrepresentation of quantity or type of goods imported or exported; ${ }^{134}$

127 Id. at 3-4.

128 See Examination Manual 241. See also The Wolfsberg Group, The Wolfsberg Trade Finance Principles (Jan. 14, 2009), available at http://www.wolfsberg-principles.com.

129 Id. at $\mathrm{F}-5$.

130 Id.

131 The non-cooperative countries list is currently a null set. See Annual Review of NonCooperative Countries and Territories 2006-2007: Eighth NCCT Review, supra note 73, at 2, 14.

132 EXAMINATION MANUAL, supra note 125 , at F-5.

133 Id.

134 Id. 
(7) A transaction structure that appears unnecessarily complex and designed to obscure the transaction's true nature; ${ }^{135}$

(8) A shipment that does not make economic sense (e.g., the use of a 40foot container to transport a small amount of relatively low-value goods) ${ }^{136}$

(9) Shipment size that appears inconsistent with the scale of the exporter or importer's regular business activities; ${ }^{137}$

(10) A type of commodity being shipped that appears inconsistent with the exporter or importer's regular business activities; ${ }^{138}$

(11) A transaction that involves receipt of cash or payment of proceeds (or other payments) from third-party entities that have no apparent connection with the transaction; ${ }^{139}$

(12) A transaction that involves front (or shell) companies; ${ }^{140}$

(13) Shipment locations or description of goods that are not consistent with the letter of credit;

(14) Documentation showing a higher or lower value or cost of merchandise than that which was declared to customs or paid by the importer; ${ }^{141}$

(15) Letters of credit that are amended significantly without reasonable justification or that include changes to the beneficiary or location of payment; ${ }^{142}$

(16) Significant discrepancies between the description of the commodity on the bill of lading and the invoice; ${ }^{143}$

(17) Significant discrepancies between the actual goods shipped and the descriptions of the goods on the bill of lading and/or invoice; ${ }^{144}$

(18) A transaction that involves the use of repeatedly amended or frequently extended letters of credit; ${ }^{145}$ and

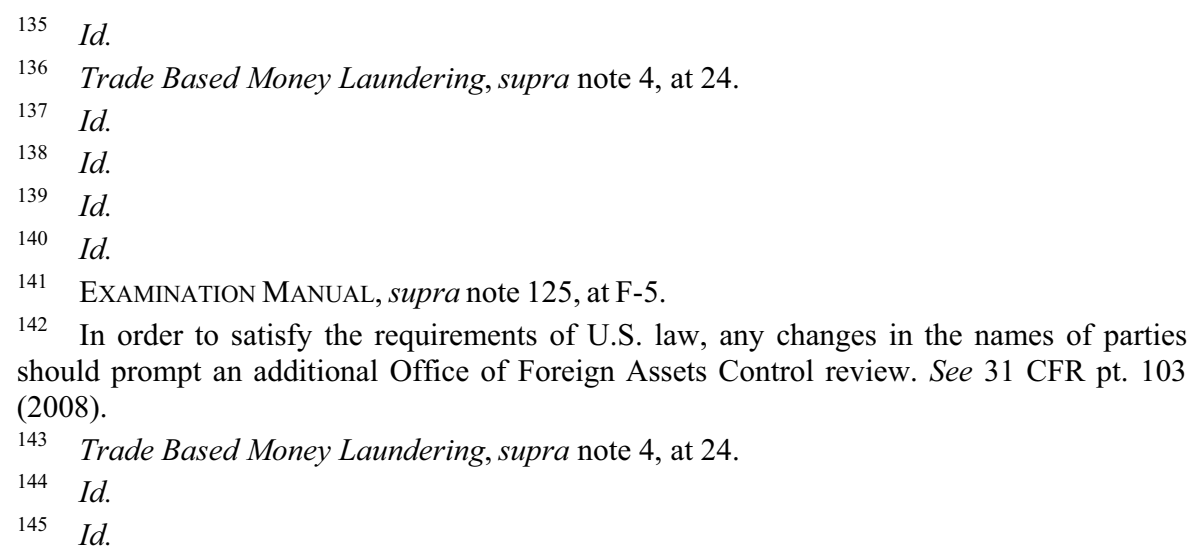


(19) A transaction that involves commodities designated as "high risk" for money laundering activities, such as goods that present valuation problems or high value, high turnover consumer goods. ${ }^{146}$

\section{Implications for Financial Institutions, Exporters, Importers, and Other Traders}

Why shouldn't financial institutions, banks in particular, do all the heavy lifting, as the 40+9 Recommendations generally require? The answer is clear: it just would not work. Even a cursory examination of the red flags set forth above reveals exactly how unworkable it would be to assign banks the primary role for this purpose. At least half of the red flags require significantly more than the documentary review required of banks to uncover suspicious or unusual TBML-related activities or transactions. Red flags one, five, six, eight, nine, thirteen, fourteen, seventeen and eighteen would require active monitoring by a party involved in the exportation, importation or transport of goods in order to determine that something was not right. ${ }^{147}$ Additionally, up to eighty percent of international trade takes place under so-called open account transactions between buyers and sellers, which generally provide the financial institution with little or no information regarding the amount of the transaction, even omitting the identities of those from whom and to whom the money is being transferred in many instances. ${ }^{148}$ This further limits the effectiveness of financial institutions in preventing TBML.

Even if a bank or other financial institution were to be involved in the transaction, it is often difficult to determine whether a transaction is unusual or suspicious. For example, red flag five refers to obvious over- or under-pricing of goods. ${ }^{149}$ How is a bank to know what the correct price of goods being exported or imported should be? ${ }^{150}$ Similarly, red flag seven-

146 Id.

147 That these suspicions are best raised and confirmed by the traders themselves is buttressed by the fact that the currently existing legal liability for actions such as simple fraudulent invoicing falls on the traders, not their financiers. See generally, Customs and Border Protection, Mitigation Guidelines: Fines, Penalties, Forfeitures and Liquidated Damages (Feb. 2004).

148 The Wolfsberg Group, The Wolfsberg Trade Finance Principles 1 (Jan. 14, 2009), available at http://www.wolfsberg-principles.com.

149 EXAMINATION MANUAL, supra note 125 , at F-5.

150 For more on abnormal pricing in international trade, readers are referred to the work of Professors Simon Pak and John Zdanowicz. Simon Pak, Stelios Zanakis \& John Zdanowicz, Detecting Abnormal Pricing in International Trade: The Greece-USA Case, 33 INTERFACES 54 (March 2003); Maria de Boyrie, Simon Pak \& John Zdanowicz, The Impact of Switzerland's Money Laundering Law on Capital Flows Through Abnormal Pricing in International Trade (Ctr. for Int'l Bus. \& Educ. Research Working Paper), available at http://ssrn.com/abstract=268444. 
teen refers to significant discrepancies that appear between the description of the goods on the bill of lading and the actual goods shipped. ${ }^{151}$ Under this red flag, a bank would be required to make a visual check of the goods, which would be difficult - if not impossible - because, even from the loading dock, how would a bank ever discover significant discrepancies, except by accident?

Many of the red flags also rely upon reference to a company's ordinary course of business. For example, red flag one refers to items shipped that are inconsistent with the nature of the customer's business, ${ }^{152}$ and red flag nine refers to shipment sizes that are inconsistent with the scale of the exporter or importer's regular business. ${ }^{153}$ These indicators require a detailed knowledge well beyond the typical pay-against-documents role of banks - to such a degree that it is unlikely a bank could develop sufficient facts to determine whether a shipment is suspicious. There might be cases in which this is obvious, but in most cases the items will either be mischaracterized in the shipping documents or the bank will not have sufficient information about the customer to know whether the product being shipped is inconsistent with normal business.

\section{Compliance Programs: Goals and Implementation}

A new Recommendation from the FATF designed to cover TBML along the lines of the 40+9 Recommendations should address a variety of non-state actors not previously addressed by the FATF. ${ }^{154}$ The new Recommendation would need to require governments to take a number of actions to ensure, among other things, that exporters and importers conduct customer due diligence, keep records, and file suspicious transaction reports, just as financial institutions and DNFBP currently are expected to do. Alternatively, should the new Recommendation follow the approach of the 9 Special Recommendations, countries would be required to adopt detection mechanisms, ${ }^{155}$ enhanced scrutiny for trade transactions with incomplete or suspicious information, ${ }^{156}$ and other measures designed to ensure that the

\footnotetext{
151 Trade Based Money Laundering, supra note 4, at 24.

152 EXAmination MANuAL, supra note 125, at F-5.

153 Trade Based Money Laundering, supra note 4, at 24.

154 See Forty Recommendations, supra note 18, at 2-6.

155 Special Recommendation IX covers the detection of cross-border transportation of currency. 9 Special Recommendations, supra note 19, at 2.

156 Special Recommendation VII covers the "enhanced scrutiny of and monitor for suspicious activity funds transfers [that] do not contain complete originator information." Id.
} 
international trade system is not used to conceal or facilitate terrorist financing. ${ }^{157}$

Implementation in the U.S. might resemble the four pillars of AML programs under section 352 of the Uniting and Strengthening America by Providing Appropriate Tools Required to Intercept and Obstruct Terrorism Act (USA PATRIOT Act): (1) internal policies, procedures, and controls; (2) designation of an AML compliance officer; (3) ongoing employee training; and (4) an independent audit function to test the AML program. ${ }^{158}$ Additionally, filing of suspicious activity reports should be required as well, and, with the U.S. Customs and Border Patrol's Container Security Initiative, suspicious activity reports in the trade arena would be made available to law enforcement agencies, including the CBP, enhancing their ability to conduct targeted screening of incoming containers and to detect illicit trade transactions. ${ }^{159}$

\section{Reducing criminal liability}

First issued in 1987, the U.S. Sentencing Guidelines (Sentencing Guidelines) provide Federal judges with a tool to set criminal sentences for those convicted of violations of Federal law. ${ }^{160}$ The Sentencing Guidelines are designed to promote uniformity in sentencing under the Sentencing Reform Act of 1984, which created the United States Sentencing Commission as an independent agency within the judicial branch. ${ }^{161}$ The Sentencing Guidelines are also employed by Federal prosecutors in settlement negotiations with criminal defendants.

In order to promote uniformity in sentencing, the Guidelines provide a formula for determining criminal penalties which includes "base levels," and aggravating and mitigating factors. First, the base level is deter-

\footnotetext{
157 Special Recommendation VII, for example, discusses including accurate and meaningful originator information. Id

158 Uniting and Strengthening America by Providing Appropriate Tools Required to Intercept and Obstruct Terrorism (USA PATRIOT) Act of 2001, Pub, L. No. 107-57, § 352, 115 Stat. 272 (2001) (codified as amended at 31 U.S.C. § 5318(h) (2001)).

159 Container SECURity Initiative, supra note 16, at 20-21. At the time of publication, much of the container security initiatives applicable to importers and exporters are voluntary measures as the U.S. Customs and Border Patrol (CBP) focuses on generating the technology and methods needed to effectively screen the millions of containers coming into the U.S. See $i d$. It is, however, safe to assume that once appropriately unobtrusive methods are developed, container security initiative measures likely will become mandatory. The more this effort is coordinated internationally, the more quickly these voluntary measures may become international standards.

160 See U.S. Sentencing Guidelines MANual (2008).

161 U.S. SEntencing Guidelines Manual 1 (2008).
} 
mined ${ }^{162}$ followed by the various aggravating and/or mitigating factors, ${ }^{163}$ in order to determine a number that corresponds to a range of months in prison for an individual or a dollar amount in fines for an organization.

Organizations are vicariously liable for the criminal activities of their agents, ${ }^{164}$ but only the individuals who committed the crimes face jail time. ${ }^{165}$ Organizations, on the other hand, may face restitution demands, disgorgement, fines and probation, and an organization found to be operating for a criminal purpose could be ordered to divest all of its assets by fine. ${ }^{166}$

Chapter Eight of the Sentencing Guidelines deals with the sentencing of organizations and suggests methods by which an organization may reduce and even potentially eliminate liability for crimes committed by its agents through measures designed to reduce the organization's culpability. ${ }^{167}$ Under the Guidelines, culpability can be reduced in two ways. The first and most important way by which an organization may reduce its culpability is to institute and maintain what the Guidelines call an "effective compliance and ethics program;" "168 the second way is by self-reporting actual or potential crimes and fully cooperating with prosecutors in any subsequent investigation. ${ }^{169}$

a. Crafting an effective compliance and ethics program

An "effective ethics and compliance program" requires that any such program be reasonably designed, implemented and enforced in order to prevent and detect criminal conduct. ${ }^{170}$ The program should be aimed at promoting "due diligence to prevent and detect criminal conduct," and

162 Under the Guidelines, the base level for money laundering is eight, plus an increase depending on the amount of money involved - ranging from no increase for offenses involving under $\$ 5,000$ to an increase of fourteen for an offense involving up to $\$ 1,000,000$. U.S. Sentencing Guidelines Manual $\S \S 2$ S1.1(a)(2), 2B1.1 (2008). The level eight corresponds to a range of zero to twenty-four months in prison, depending on criminal history, and a level of twenty-two corresponds to a range of 41-105 months in prison. Id. at ch.5, pt. A, table.

163 Mitigating Factors are called "downward departures" in the Guidelines, and include age, physical condition, criminal history, accepting of responsibility, and aiding the authorities. Id. $\S 5 \mathrm{G} 1.3(\mathrm{E}), 5 \mathrm{H} 1.1,5 \mathrm{H} 1.4,5 \mathrm{~K} 2.0 \mathrm{cmt}$. background (2008).

164 See Restatement (ThiRd) of AgEncy § 2.04 (2006). See also U.S. Sentencing GUIDELINES MANUAL ch.8, introductory cmt. (2007).

165 U.S. SENTENCING GUIDELINES MANUAL ch.8, introductory cmt. (2008).

166 Id

167 Id.

168 Id. $\S 8 \mathrm{~B} 2.1$.

169 Id. $\S 8 \mathrm{C} 2.5(\mathrm{~g}) .$.

$170 \quad$ Id. $\S 8 \mathrm{~B} 2.1(\mathrm{a})(2)$. 
should "otherwise promote an organizational culture that encourages ethical conduct and a commitment to compliance with the law."

The Sentencing Guidelines instruct that "due diligence" and "commitment to compliance" with legal and ethical standards require, at a minimum:

(1) Reasonable oversight by the board regarding content, implementation, operation, and "general[] effective[ness]" of the compliance and ethics program; ${ }^{172}$

(2) Ensuring the effective operation if the program by high-level managers; ${ }^{173}$

(3) The designation of at least one specific individual responsible for dayto-day operational responsibility, ${ }^{174}$

(4) Reasonable efforts to ensure that those with substantial authority will comply with the program; ${ }^{175}$

(5) Continuing and periodic training; ${ }^{176}$

(6) Monitoring, auditing, periodic evaluations, internal reporting, and other "reasonable steps" to ensure effective operation; ${ }^{177}$

(7) Setting up appropriate incentives for compliance and disincentives for noncompliance, ${ }^{178}$ and

(8) If criminal conduct is detected, making any necessary modifications to the program to ensure compliance in the future. ${ }^{179}$

In general, the elements required by a compliance program under the Guidelines parallel, and in some cases are virtually identical to, those found in the AML program requirements of the USA PATRIOT Act. For example, the requirement of "policies, procedures and internal controls" under section 352 of the PATRIOT Act corresponds with the Guidelines' requirement for board oversight of the implementation and the effectiveness of the program, ${ }^{180}$ effective operation by high-level managers, ${ }^{181}$ incentives

$171 \quad$ Id. $\S 8 \mathrm{~B} 2.1(\mathrm{a})$.

172 Id. $\S \S 8 \mathrm{~B} 2.1(\mathrm{a})(1)-(2), 8 \mathrm{~B} 2.1(\mathrm{~b})(2)(\mathrm{A})$.

173 Id. $\S 8 \mathrm{~B} 2.1(\mathrm{~b})(2)(\mathrm{B})$.

174 Id. $\S 8 \mathrm{~B} 2.1(\mathrm{~b})(2)(\mathrm{C})$.

175 Id. $\S 8 \mathrm{~B} 2.1(\mathrm{~b})(3)$.

176 Id. $\S 8 \mathrm{~B} 2.1(\mathrm{~b})(4)(\mathrm{A})$.

177 Id. $\S 8 \mathrm{~B} 2.1(\mathrm{~b})(5)$.

178 Id. $\S 8 \mathrm{~B} 2.1(\mathrm{~b})(6)$.

179 Id. $\S \S 8 \mathrm{~B} 2.1(\mathrm{~b})(7), 8 \mathrm{~B} 2.1(\mathrm{c})$.

180 See 31 U.S.C. $\S 5318(\mathrm{~h})(1)(\mathrm{A})$ (2001); U.S. SENTENCING Guidelines ManuaL $\S \S$ 8B2.1(a)(1)-(2), 8B2.1(b)(2)(A) (2008).

181 See U.S. Sentencing Guidelines MAnual $\S 8$ B2.1(b)(2)(B) (2008). 
for compliance, ${ }^{182}$ and modification of the program if criminal conduct is detected. ${ }^{183}$ The requirement of the appointment of an AML compliance officer under section $352^{184}$ is virtually identical to the Sentencing Guidelines recommendation for the designation of an individual with day-to-day responsibility. ${ }^{185}$ Similarly, the USA PATRIOT Act requirement regarding training ${ }^{186}$ is virtually identical to the Guidelines' recommendation regarding continuing and periodic training programs, ${ }^{187}$ and the PATRIOT Act independent $\mathrm{AML}$ audit requirement ${ }^{188}$ is encompassed within the Guidelines' recommendation regarding auditing, periodic evaluations and internal reporting. ${ }^{189}$

Consequently, corporations adopting AML program requirements even when not required by law will go a long way toward mitigating potential criminal liability for TBML. The need for programs designed to mitigate criminal liability also will depend upon the likelihood of criminal conduct: "If, because of the nature of the organization's business, there is a substantial risk that certain types of criminal conduct may occur, the organization shall take reasonable steps to prevent and detect that kind of criminal conduct." ${ }^{190}$ With TBML now identified as one of the three major avenues of money laundering, businesses engaged in international trade must take notice of this risk associated with their business or face higher criminal penalties.

b. Culpability score: reducing or increasing fines

Similar to the way sentencing is determined for individuals, the Guidelines call for the determination of a base level fine, which is then reduced or increased depending upon the organization's culpability, which is measured by a "culpability score." 191

The "culpability score" is a multiplier applied to amount of the fine. ${ }^{192}$ Starting with a multiplier of one, which corresponds to a culpability score of five, the Guidelines list considerations that increase or decrease an

\footnotetext{
$182 \quad$ See id. $\S 8 \mathrm{~B} 2.1(\mathrm{~b})(6)$

183 See id. $\S \S 8 \mathrm{~B} 2.1(\mathrm{~b})(7), 8 \mathrm{~B} 2.1(\mathrm{c})$.

184 See 31 U.S.C. $\S 5318(\mathrm{~h})(1)(\mathrm{B})(2001)$.

185 See U.S. SENTENCING Guidelines MANuAL § 8B2.1(b)(2)(C) (2008).

186 See 31 U.S.C. $\$ 5318(\mathrm{~h})(1)(\mathrm{C})(2001)$.

187 See U.S. SENTENCING Guidelines Manual § 8B2.1(b)(4)(A) (2008).

188 See 31 U.S.C. $\$ 5318(\mathrm{~h})(1)(\mathrm{D})$ (2001).

189 See U.S. SEnTENCing Guidelines MAnual $\S 8$ B2.1(b)(5) (2008).

190 Id. $\S 8 \mathrm{~B} 2.1 \mathrm{cmt} . \mathrm{n} .6$.

191 Id. $\S 8 \mathrm{C} 2.5$.

192 Id. $\S 8 \mathrm{C} 2.4 \mathrm{cmt}$. background.
} 
organization's culpability; this determines how large the fine will be. ${ }^{193}$ When high-level personnel involve themselves in the crime or establish a culture of tolerance for criminal activity, the culpability score increases. ${ }^{194}$ The score also increases if the organization has a prior history or has obstructed justice. ${ }^{195}$

If the organization had an "effective compliance and ethics program" in place under its own initiative, as opposed to having such a program in place because of a court order, then the culpability score decreases by three. ${ }^{196}$ Further, if an organization quickly reports a discovered offense prior to the threat of investigation, fully cooperates in the subsequent investigation, and "clearly demonstrate[s] recognition" of its responsibility, then the culpability score decreases by five. ${ }^{197}$

If the organization does not self-report, but still cooperates fully and clearly accepts responsibility, then the culpability score decreases by two. ${ }^{198}$ A clear acceptance of responsibility is worth a decrease of one. ${ }^{199}$

So, as an example, if the high-level personnel of an organization with 200-1,000 employees and with no prior history have engaged in criminal conduct, then the culpability score for the organization would be eight because three would be added for the involvement of high level personnel to the base of five. Further, under this example, the maximum recommended multiplier on the fine would be $3.2 .^{200}$ If, however, the organization in question had an effective compliance and ethics program, quickly self-reported, fully cooperated, and accepted responsibility, then the culpability score would be zero, and the corresponding maximum multiplier is a mere .2meaning that the $\$ 175,000$ fine would be reduced to only $\$ 35,000$.

c. Further guidance on compliance from the Department of Justice

The U.S. Department of Justice also has issued a memo on the liability of organizations entitled "Federal Prosecution of Business Organizations" (McNulty Memo). ${ }^{201}$ The McNulty Memo instructs prosecutors to consider the same factors listed in the Sentencing Guidelines in deciding

\footnotetext{
193 Id. $\S 8 \mathrm{C} 2.5$.

$194 I d$. $\S 8 \mathrm{C} 2.5(\mathrm{~b})$. Also, the larger an organization is, the more the score increases. See id.

195 Id. $\S \S 8 \mathrm{C} 2.5(\mathrm{c})-(\mathrm{e})$.

196 Id. $\S 8 \mathrm{C} 2.5(\mathrm{f})(1)$.

197 Id. $\S 8 \mathrm{C} 2.5(\mathrm{~g})(1)$

$198 \quad I d . \S 8 \mathrm{C} 2.5(\mathrm{~g})(2)$.

199 Id. $\S 8 \mathrm{C} 2.5(\mathrm{~g})(3)$

200 See id. $\S 8 \mathrm{C} 2.6$.

201 United States Department of Justice, Memorandum Regarding Principles of FEDERAl ProseCution of Business OrganizAtions (2006), http://www.usdoj.gov/dag/sp eech/2006/mcnulty_memo.pdf [hereinafter McNulty Memo].
} 
whether or not to prosecute an organization. Some of the considerations are the existence of a compliance program, prior history, timely disclosure, and management complicity. ${ }^{202}$

Although "the Department has no formal guidelines for corporate compliance programs," in assessing the adequacy of the organization's compliance program, the memo indicates that several factors should be taken into consideration. ${ }^{203}$ These factors include the following: whether the program is well designed and comprehensive, and whether the program is part of normal business operations or is "merely a paper program;" the extent and pervasiveness of criminal conduct in the organization; the seriousness and duration of misconduct; the promptness of discovery and disclosure; revisions to the compliance program to prevent future misconduct; the board's independent oversight of corporate activity and whether the board receives sufficient information under the program to evaluate its decisions; and the sufficiency of internal auditing. ${ }^{204}$

The memo also instructs prosecutors to seek the expertise of other agencies in evaluating the compliance program, such as the Environmental Protection Agency, the Securities and Exchange Commission, and U.S. Department of Health and Human Services. ${ }^{205}$

As "[c]urrent and former U.S. Department of Justice officials have stated to the Advisory Group that the U.S. Department of Justice has declined prosecutions based on the existence of an effective compliance program," making sure that the organization designs, implements, and maintains a sound compliance program can significantly reduce the organization's exposure to criminal liability. ${ }^{206}$

d. Additional considerations on reducing culpability: FATF best practices

The FATF's Best Practices Paper supports the extension by countries of existing AML/CFT strategies to combat TBML, such as:

(1) training of law enforcement officials, customs officials, bank examiners and the private sector, ${ }^{207}$

(2) "disseminat[ing] TBML typologies, red flag indicators and sanitised case studies" as part of any training; ${ }^{208}$

202 Id at 4

203 Id. at 14.

204 Id.

205 Id. at 15.

206 Paul E. McGreal, Legal Risk Assessment After the Amended Sentencing Guidelines: The Challenge for Small Organizations, 23 CORP. Couns. REV. 153 (2004).

207 Best Practices Paper, supra note 7, at 2.

208 Id. at 5. 
(3) conducting further study of the issue at the national and regional levels; ${ }^{209}$

(4) cooperating with intelligence gathering and investigations at the international level; ${ }^{210}$

(5) enhancing domestic information sharing among government agencies and ministries by developing "a domestic mechanism to link the work of authorities responsible for collecting, analysing and storing trade data with authorities responsible for investigating money laundering and terrorist financing" with appropriate safeguards for the protection of privacy; ${ }^{211}$

(6) creating a "Trade Transparency Unit," akin to a Financial Intelligence Unit, in order to collect, analyze and share trade data; ${ }^{212}$ and,

(7) implementing the measures outlined above "with a view to ensuring that legitimate trading activities are not unreasonably hindered or obstructed."213

What stands out most clearly in the Best Practices Paper is the emphasis on the need for more and better information regarding trade patterns before imposing any burdens on states, financial institutions, or other private sector actors. "Since [TBML] has received relatively little attention from policy makers to date," ${ }^{, 14}$ the "objective of [the] paper is to improve the ability of competent authorities to collect and effectively utilize trade data." 215

It is also clear, however, that the FATF is not ready to adopt significant measures to require states, financial institutions, DNFBPs or traders and others in the supply chain to take action on TBML. After noting that "there is a need . . . for competent authorities to enhance their ability to identify TBML/FT techniques," the FATF suggests that "countries could agree to incorporate TBML/FT into existing training programs on AML/CFT." $" 216$

To that end, the FATF has provided various techniques for countries to analyze trade data to spot TBML trends that may be useful for companies in designing anti-TBML procedures, including the following:

(1) comparing domestic and foreign import and export documentation, prices, and other data;

$\begin{array}{ll}209 & \text { Id. } \\ 210 & \text { See id. at } 7 . \\ 211 & \text { See id. at } 5 . \\ 212 & \text { See id. at } 8 . \\ 213 & \text { Id. at } 7 . \\ 214 & \text { Id. at } 1 . \\ 215 & I d \text {. at } 5 . \\ 216 & \text { Id. at } 2 .\end{array}$


(2) identifying parties to each transaction;

(3) checking transactions for known irregularities or risk indicators, such as origins, routes, and parties;

(4) comparing import/export information with tax declarations; and

(5) taking follow-up actions when anomalies or red flags appear in order to ensure the integrity of the transaction. ${ }^{217}$

2. Reducing civil liability: In re Caremark and the duty to monitor

By crafting a program to mitigate or avoid criminal liability for TBML, organizations may also act to reduce civil liability. For example, under Delaware law, an organization leaves itself exposed to civil liability if it does not implement and maintain compliance programs suited to the nature of the organization and its line of business. ${ }^{218}$ The McNulty Memo specifically states that it is beneficial for organizations outside of Delaware to also follow the precedent set in In re Caremark (Caremark). ${ }^{219}$

In Caremark, shareholders filed a derivative suit against Caremark International Incorporated for criminal liabilities associated with referral payments prohibited under the Anti-Referral Payments Law and related Department of Health and Human Services regulations. ${ }^{220}$ After noting that Section 141 of Delaware General Corporation Law requires that the board of directors receive timely information in order to satisfy its duty to monitor corporate activities, Chancellor Allen emphasized the importance of the Sentencing Guidelines, writing that "[a]ny rational person attempting in good faith to meet an organizational governance responsibility would be bound to take into account this development and the enhanced penalties and the opportunities for reduced sanctions that it offers." ${ }^{221} \mathrm{He}$ continued by stating that the board must "assur[e] themselves that information and reporting systems exist in the organization that are reasonably designed to provide to senior management and to the board itself timely, accurate information sufficient to allow" informed business judgments. ${ }^{22}$

Thus, a failure to implement a compliance program reasonably designed to deliver accurate information in a timely fashion exposes the board

\footnotetext{
217 Id. at 3.

218 See In re Caremark, 698 A.2d 959 (Del. Ch. 1996) (holding that directors must inform themselves about corporate affairs by establishing compliance systems in order to invoke protection under the business judgment rule).

219 McNulty Memo, supra note 201, at 14.

220 Caremark, 698 A.2d at 961-62.

221 Id. at 970.

222 Id.
} 
and the organization to civil liability as well as criminal liability. ${ }^{223}$ As stated in a subsequent case, "Caremark and its progeny have held that directors can be held culpable in the monitoring context if they breach their duty of loyalty by 'a sustained or systemic failure . . . to exercise oversight,' or 'were conscious of the fact that they were not doing their jobs [as monitors].", 224

In Caremark, Chancellor Allen considered that, despite Caremark's criminal liability and $\$ 250,000,000$ settlement, Caremark's compliance program met the fiduciary obligations of the board. ${ }^{225}$ Because Caremark and its predecessor had issued and periodically updated its guidelines for employee compliance, had conducted ongoing training, had an internal auditing system, had hired an external company to conduct an independent external audit, and had engaged in a process of increasing management supervision and in-house contract review, Caremark avoided civil liability in addition to the criminal penalties it incurred. ${ }^{226}$ This decision was affirmed again in September 2008, when the Delaware Chancery held that "[w]here, as here, the board employed a special committee that met frequently, hired reputable advisors, and met frequently itself, a Caremark-based liability theory is untenable."227

\section{CONCLUSION}

Although AML/CFT measures have succeeded in restricting the two traditional avenues of money laundering, namely, the abuse of financial intermediaries and the physical movement of money across borders, criminals and terrorist organizations have turned to TBML to conceal and legi-

223 See id. ("[A] director's obligation includes a duty to attempt in good faith to assure that a corporate information and reporting system, which the board concludes is adequate, exists, and that failure to do so under some circumstances may, in theory at least, render a director liable for losses caused by non-compliance with applicable legal standards.").

224 In re Lear Corp. Shareholder Litigation, Cons. C.A. No. 2728-VCS 24 (Del. Ch. Sept. 2, 2008).

225 See Caremark, 698 A.2d at 971-72 (recognizing that a violation of criminal law does not necessarily trigger a breach of corporate fiduciary duty).

226 Id. at 962-64. A 2006 Delaware Supreme Court decision affirmed the holding of Caremark and clarified that civil liability will not attach unless "(a) the directors utterly failed to implement any reporting or information system or controls; or (b) having implemented such a system or controls, consciously failed to monitor or oversee its operations thus disabling themselves from being informed of risks or problems requiring their attention." Stone v. Ritter, 911 A.2d 362, 370 (Del. 2006).

227 Lear Corp. Shareholder Litigation, Cons. C.A. No. 2728-VCS at 26 accord Stone, 911 A.2d at syllabus (holding that "necessary conditions predicate for director oversight liability [include] utterly failing to implement any reporting or information system or controls, or consciously failing to monitor or oversee operations of such a system."). 
timize their funds, as this is a channel that remains relatively untouched by AML/CFT efforts internationally. This abuse of the global trade network has received increasing recognition from the FATF, the international standard setter, as the next front in AML/CFT. Because TBML methods may be used not only to launder money, but also to finance international terrorism, to facilitate weapons proliferation, and to conceal and transport WMDs and the materials used to make them, those in the international supply chain must find ways to safeguard their businesses.

Given these considerations, companies involved in the international trade supply chain should design, implement, and maintain a program to detect and prevent TBML. Such a compliance program should be able to detect and report transactions that involve, at a minimum, any of the red flags $^{228}$ and incorporate the guidance provided by the FATF and the U.S. Government. ${ }^{229}$ The program should include internal policies and procedures approved by the Board of Directors and senior management that provide for the identification of customers and other parties to a trade transaction, record keeping and the filing of suspicious transaction reports (in the U.S., suspicious activity reports or SARs); the designation of an AML/CFT compliance officer; ongoing training; and an independent AML/CFT audit.

A central concern should be identifying and monitoring transactions out of the ordinary course of business, including those with frequent or numerous alterations to documents such as letters of credit and bills of lading. A compliance program should also be able to detect the involvement of other parties to the transaction, those who may benefit by it, and shell companies. Finally, large organizations heavily involved in international trade should ensure that all who are parties to the transaction, as well as those in the supply chain with respect to a particular transaction, be subject to some level of due diligence, depending on their role and relevant risk parameters such as geographic location, nature of the goods and services, and complexity and size of the transaction.

The risks are increasing as containers enter our countries without being inspected, as predicate crimes ${ }^{230}$ such as narcotics trafficking, human trafficking, and terrorist financing are committed across borders, and as logistical support for terrorist activities such as the movement of weapons of mass destruction is disguised or concealed in international trade. ${ }^{231}$ There is

\footnotetext{
228 See supra Part IV.B.

229 See supra Part IV.D.

230 Under U.S. law, the underlying crimes to the offense of money laundering are called "specified unlawful activities." 18 U.S.C. § 1956(c)(7) (2000).

231 See generally Herbert V. Morais, Fighting International Crime and Its Financing: The Importance of Following A Coherent Strategy Based on the Rule of Law, 50 VILL. L. REV. 583 (2005) (providing an analysis of the connection between the fight against money laundering and the expanding definition of international crime).
} 
every expectation that the FATF, with its renewed mandate, will continue to take action on TBML; for now, all that remains uncertain is whether the FATF will add a 41st Recommendation to its current 40 Recommendations, ${ }^{232}$ a Special Recommendation X to its current 9 Special Recommendations, or take some other course of action that has a less concerted effect on international trade. ${ }^{233}$ In whatever approach the FATF takes, to be effective, it should encompass not only the financial institutions and DNFBP addressed in the past, but also all those identified by the FATF in its Best Practices Paper, including importers, exporters, freight forwarders, shippers and air couriers. ${ }^{234}$

Because most multinational companies would fit squarely within this scope, non-financial companies that may not now be paying close attention to the 40+9 Recommendations would be significantly impacted. Given the global nature of money laundering and terrorist financing, and the convergence of national AML/CFT laws with the FATF 40+9 Recommendations, companies may ignore their TBML risk only at their peril, potentially incurring both civil and criminal liability. Without developing customer identification procedures and other safeguards commensurate to the risk that TBML poses, a company makes itself vulnerable to aiding, whether intentionally or not, a transnational criminal or terrorist organization in need of moving wealth, weapons, or chemical, biological, or nuclear materials across borders. Not only does this pose significant reputational risks, but, with the increasing attention being paid to TBML in the fight against international terrorism, the legal risks associated with failing to safeguard against TBML can no longer be ignored by non-financial businesses operating in the international trade supply chain.

\footnotetext{
232 Forty Recommendations, supra note 18.

2339 Special Recommendations, supra note 19.

234 Best Practices Paper, supra note 7, at 2 ("The term trader refers to anyone who facilitates the exchange of goods and related services across national borders, international boundaries or territories. This would also include a corporation or other business unit organised [sic] and operated principally for the purpose of importing or exporting goods and services (e.g. import/export companies).").
} 